\title{
The Strategic Dimension of the Straits Area According to the New National Metropolitan Spatial Planning and to the European Space: Strategic Corridor Platform Project
}

\author{
Francesca Moraci ${ }^{1, a}$ \\ ${ }^{1}$ Mediterranea University of Reggio Calabria - Department for Architecture and Territory, Via \\ Melissari, 89124 Reggio Calabria, Italy \\ afmoraci@unirc.it
}

Keywords: Strategic Corridor Platform, Metropolization, Territorial Intelligence, Metropolitan Agenda, Functions and Strategies.

\begin{abstract}
For some time now, following the constitutional reform, the debate on the metropolitan city has been reignited. The topic has been at the centre of attention given that cohesion policies attribute to metropolitan cities a key role in planning and the constitutional reform seems to have given an answer to the spending review which wipes out the provinces and "formally" identifies the European Strategy under the form of a programmatic suitability of intermediate metropolitan level. This level should counterbalance the municipal egoism which provides a distorted interpretation of subsidiarity which has marked planning since the revising of Title V. Very few are acquainted with the implications and complexities of these entangled mechanisms which will fail if all conditions are not met whether they be effective, "nominal" or opportunity related. This explains why the term Metropolitan City is preferred to conurbation, agglomeration or metropolitan area. Metropolitan Area and City do not coincide - the area [1] is in a portion of territorial recognition which entails attractive and competitive factors, the city is identified as such only if within the territorial organization - that explains why the creation of both must be ensured: the city must be promoted in terms of competition, with or without a demographic dimension, by fostering the shared political project and by creating relational and productive conditions to attract and offer services and what else is necessary. What makes the difference is how to build and what to build. The strategy and the role of the future Metropolitan City of Reggio Calabria and Messina stem from two different regulations and from the attempt to integrate interregional functions through the project I put forward: the strategic corridor platform of the Straits area. The platform is a non-confined territorial dimension which encompasses the two metropolitan cities and shares relational functions and understandings with the vast territory. It fully exploits the possibilities and available reforms in order to organize and provide the territory with competitive and functional dimensions so as to compete in Europe and in the Mediterranean. The prototype-project, the first part of the study has already been published, fosters an idea of governance and urban system which will devise, through future cohesion policies and multidimensional strategies, a single strategic vision of the territory able to dialogue at a local and Euro-Mediterranean level with the new scale economies and meet the challenges of 2020-2050. Without going into detail, the project proposes and organizes the intangible functions of the Area [new assets and networking] so as to satisfy the demand for services and infrastructures physical and non-physical (functional and international indicator).
\end{abstract}

\section{The strategic corridor platform project}

The Europe of metropolitan Cities (cities-regions) 2014-2020 outlines a new urban vision in terms of space, spending capacity, competitiveness and services. The competitors could be: the Paris-Le Havre System and Greater London in the Mega City Region. These towns represent the intelligent nodes (this explains the relentless pursuit of smart city as a prerequisite to the PON national metropolitan candidature) of the European space linked to the European networks - TEN-T and to the intangible grids (energy and ICT): the Corridors which the collective imagination tends to endow with a negative connotation. These connections between cities and urban areas/territories with "variable 
dimensions" (second option of the European experiment) can be classified in two groups: core network of European interest and comprehensive network of national interest. Those cities who are unable to reach a European corridor in less than 30 minutes will not receive funds (connecting Europe), because lying outside the European space "CORE". That is why thought is being given to the Rome-Milan platform.

The "Metropolitan Area" is an opportunity but we must play the role to the full. The "title" metropolitan city is not sufficient to prove that the method has been changed and that the time is right to adopt the new "territorial system" according to the indications and vision of the European policy. The Italian constitutional reform, which should transpose and articulate national documents according the European vision, does not seem to respond to the innovative planning capacity of the territory/city.

The need is felt to better clarify the national urban policy at present administered by different ministries -evoked as Urban agenda-, to set up the 2020 strategic Agenda and to choose the ideal Country Projects to invest in at a European level. The New Country Projects (the infrastructural project becomes strategic and development related) envisage five macro regions. The Southern Macro-region and islands would cover the south focusing on high speed links between the cities, in order to open up a vast domestic market, and on the role of southern ports oriented towards the new freight transport axis in the southern Mediterranean. However, various contradictions exist with reference to infrastructural and logistic planning and to the reform of Port Authorities. If the metropolitan solution should become the intermediate dimension with the privilege of engaging a dialogue directly with Europe, which "cities" would become the "intelligent hubs"? Which actions must be taken to meet the vision objectives and render the cities more attractive? Will Italy welcome the greatest number of smart cities? And the South? What must the cities and the territories do to stand as candidates? Are all cities eligible? Obviously not.

Immediate understanding of the action to be taken is necessary. The southern cities which must bridge the structural gaps must prove "to be able" in a country like Italy which ranks $27^{\text {th }}$ out of 28 countries in terms of expenditure, ideas, strategies, innovation, supply of services, infrastructure, quality of life and attractiveness. The location (Straits Area), which in another country would be strategic as part of the Straits of Europe project, complicates the situation because the lack of an infrastructure policy (counter metropolization) overshadows its potential as source of funding, integrated policy and independent authority.

While the city of Reggio Calabria has a well-defined legal status, the city of Messina is suffering for a series of reasons namely the reform of the port authorities and the will of many municipalities to create autonomous consortiums. The gateway position should only prove attractive and of regional interest, instead it has the opposite effect: lifeless and of no contractual interest.

Furthermore, on the Sicilian shore the reform can be even more "unusual". The nine provinces will be replaced by nine consortiums and three metropolitan cities. The debate focuses on the administrative borders [2] rather than on the functions just barely mentioned in the Delrio proposal. Rank, functions and strategy do not seem to be at the centre of debate.

The project I propose is the result of studies, some of which have been published, and refers to the characteristics/contents of the metropolitan area and of the metropolitan city as well as to the construction of factors of metropolization for the cities of Messina and Reggio Calabria. In the specific case of those cities, in the absence of any economic factor of metropolization, opportunity and geographical location play a start-up role, provided that they are combined with governance capacity, a start-up strategy and the local resources that already exist or are to be activated through the Urban Agenda of the Strait Area and the social pact [3]. The project goes beyond the dimension of the metropolitan area, which is being brought to the debate, and casts it into a logic of territorial ebullience and of strategic corridor platform that embraces the problems of the Straits (of Europe), in their European dimension, and moves on to a first attempt of integration between Messina and the metropolitan city of Reggio Calabria (including the town of Gioia Tauro). Then, it develops through an agreement with the eastern area of Sicily, as far as Siracusa, and with Calabria, thus forming a 
network of metropolitan cities in the south of Italy, in a logistic vision of the Straits as the heart of the Mediterranean.

This process will fracture the current modes of local governance and re-establish others. The borders and the Statute of the Metropolitan City will be the first issues to deal with, followed by its relationship with the Straits area and with the metropolitan city of Reggio Calabria. When tackling the topic of the city, all the concepts are seemingly simple and obvious, yet, today, it requires the local and national policy to be fully converted to a European perspective, and not only. It also calls for the development of consistent and cross-scale policy strategies as well as for the verification and, sometimes, the construction of factors of metropolization to cope with spontaneous pressures or occasional niches of the image communication market that may confuse its mission. At the same time, owing to what has been mentioned above, it is fundamental to find new approaches to the construction of these new metropolitan cities that should attract material and immaterial flows [4] and relaunch them in a network; develop all the necessary infrastructures; and take a leading role in the regional context. In short, they should be in the flows and capture the flows, even the immaterial ones that originate a new urban ecosystem.

The metropolization of the city is a complex process (above all when it is endured and forced rather than spontaneously started or planned). The metropolitan rank will depend not only on the agglomeration, but also on factors of metropolization which will guide the organization of its territory and its way of presenting itself, and its ideas about the knowledge-based economy, environment and energy, to investors.

The relationship with Europe and the Mediterranean is the second issue in which the city should play its role. But which role? Are the cities of Messina and Reggio Calabria to be considered as Agglomeration, Union of Metropolitan Cities, Integrated Area or Metropolitan Area?

With regards to the Straits Area, it is crucial to recover an "internal" role (of each city of the Strait; of the cities in their complementary and cooperative relation) and an "external" role meant as relationship with the Regions, with the cities of the Straits, with Europe and the Mediterranean. The role of gateway is recognized as such if it is defined in an interregional area where it is possible to experiment with hypotheses of integrated territorial investments that may assure the cohesion of territory and interterritory. In addition, such hypotheses of investments, which are made in variable geometry territories, imply the test conditions of the prototype-project I put forward through this specific type of corridor platform. This will require the Regions to be actively involved in policy-making in Europe; to set objectives in relation to the challenges to face, without being distracted by easy expenditure in single sectors; and to take into account transregional coordination processes (the case of Calabria-Sicily/Straits area is a good example) in order to interact and exploit synergies in a project of shared growth. Open innovation, creativity and development of infrastructures are issues underlying initiatives, such as Straits of Europe and the idea of a corridor platform - first stretch of a sea corridor - in which a special Port Authority operates; the association of the two universities of the Straits to establish a Polytechnic University of the Straits, which may favour certain fields of studies and specialization and negotiate, in Europe, the investments in education that are deducted from the 3\% rate; the energy corridor and the offshore energy park; the role of Milazzo as an infrastructured logistic platform; the digital corridor through the Mediterranean Traffic and Safety Management Centre. Actually, the Straits Area could have been given the supplementary function related to the interregional agreements on territorial cooperation provided for by the penultimate paragraph of art. 117 of the Italian Constitution, introduced by the constitutional law n. 3/2001, which establishes the power of the Regions to come to agreements with other Regions with the purpose of improving the exercise of their functions, even by identifying joint bodies and ratifying the development of infrastructures and territorial development policies by regional laws. In order to bridge these gaps, it is necessary to define a social guarantee pact, which could include the Statute of the metropolitan city and the Agreement for the Straits area.

Only in this context does the smart city metaphor (application of ICTs to the city) fit the creativity which should be mobilised as a strategic dimension of the urban policy and as a precondition to be 
competitive in Europe by using the specific National Operational Plan as a sort of accompanying action, in which start-up is based on research and innovation. That means to apply certain paradigms, such Talent, Technology and Tolerance, to the territory so as to define the DNA of these cities and their complementary Territorial Intelligence. It is a sort of identity card, a recognizable and unique, spatial and aspatial profile that highlights peculiar and unrivalled characteristics and relies on knowledge spillover to produce the value of the city through the city brand index. The political and territorial project should come from the search for integration between an additional community action, envisaged for the 2014-2020 programming period, and an ordinary action taken by the government at national, regional and intermediate level. As Barca states, those parallel actions - the additional and the ordinary ones - demand a framework of institutional, organizational, political and administrative reforms in order to give institutional shape to the policies addressed to urban areas [5]. Such policies need to be reformulated in the following points:

1. The need for a national town planning law and the regional coherence, as well as other regional and national regulations concerning environmental responsibilities.

2. The resistance of local ruling classes to the establishment of coalitions, unions and town planning strategies.

3. Public finance constraints and reduction in transfers, which, in a context of unfinished reforms of the local taxation, decentralization and reorganization of local authorities, prevent from valorising investments as well as keeping the current levels of services and of the ordinary maintenance of the existing infrastructure.

4. Adequate infrastructural policies consistent with the country's modernization and position in the European space. This particularly applies to the regions in the south of Italy.

If a prompt action is not urgently taken the existing trend will discourage innovation and repulse the ideas arising from creative dimension. We will continue losing confidence in the institutions with a serious social exclusion which will result in a greater impoverishment of the quality of life and in a sequence of upsetting events whose course will soon be irreversible if we only rely on Community resources.

In my study referred to above (UrbanPromo 2009) it is shown how the other classifying and performing procedure is based on the potential success of metropolitan cities, comparing metropolitan cities and areas having a high functional and international level to metropolitan cities and areas with an old industrial tradition defined according to the following criteria and procedures of reading/evaluation:

$\checkmark$ Functional Index, calculated considering administrative functions, national and international economic conditions, connectivity, position in the knowledge-based economy;

$\checkmark$ Internationalization Index, based on the presence of seats of worldly known societies as well as on the existence of air connections on a global scale;

$\checkmark$ GDP, Gross Domestic Product.

It emerges from that study that, in Europe, London and Paris are at the top among the "winning" cities. In particular, London has a functional index of 9.7, an internationalization index of 10, a GDP of 136 in 1995, and this figure was confirmed in 2005; whereas Paris has a functional index of 9.5, an internationalization index of 10.8, a GDP of 152 in 1995, and this figure was confirmed in 2005. On the contrary, Rhin-RhuR and West Midland occupy the first places among the "losing" cities. Rhin-RhuR has a functional index of 6.2/5.7, an internationalization index of 1.2/2.3, a GDP of 104 in 1995, and this figure underwent a slight decrease in 2005 (103); whereas West Midland has a functional index of 5.1, an internationalization index of 0.9, a GDP of 100 in 1995, against 93 in 2005.

Further analyses - carried out also on the city of Reggio Calabria - suggest that success factors and conditions for metropolitan cities may be identified as follows:

- location factors (European area), along the axis of a corridor or a network, as a multimodal gateway for specific activities or at the junction of important rail and/or air transports;

- structural economic factors, from the institutions, to the market and to the international quality of research; 
- social factors, effective policies of social redistribution, availability of good quality accommodation, strong social mixity;

- heritage and cultural factors, importance of well preserved and valued historical heritage, policies for international cultural diffusion, image and value of image;

- environmental factors, prestigious and preserved environmental sites; high quality landscapes, hydrogeological security;

- urban governance, multi-level dialogue, policies of urban marketing, management of urban conflicts and of urban security, functional organization and cutting of red tape.

- Finally, the citizens' responsibility and institutional intelligence, embodied by brave and clever politicians who assume responsibility for control centre and coordination of the relationship between urban (local-regional-national and European) policy and the positioning strategy of the city to the interregional and local dimension, even through town planning instruments, in order to make the programming aspects of large area consistent with ordinariness of municipal town planning - which in Sicily is still anchored in the old Law U 71/'78, whereas in Calabria in Law LUR 19/2002 .

Therefore, how to combine two views of the world in the absence of a national policy planned in cooperation with the regions - which should negotiate in Europe? On the one hand, there is the view proposed for urban areas, including new network spaces, inclusive society, cohesion policies, as a unique continental and territorial bloc in the world economy - between the African coastal emergent countries in the Mediterranean Sea and "CHIMERA"- China, Middle East and America -; on the other hand, there is the stifling view we are debating now, interpreted by national laws of a heavy, local, rhetorical and myopic reform which does not mirror any more either the society or the spatial and administrative model we need for new urban economies. The uniformity of the administrative system needs to be broken in terms of differentiated self-government. How to implement the modernisation of public action [6] taking advantage of this opportunity through the dynamic, open and creative city of project territories, inverting the traditional method of town planning? How to assure transcalar view with local needs for the city as a common good? How to combine all the rights for a common horizon?

We have no time anymore, when space and time themselves are residual descriptors for the functioning of the world in terms of network and globalization. Not only because they sped up the process of social change and absorption of resources in respect of an impoverishment of territory and an overlapping of casual spaces in the city, but also because the network produces a virtual space capturing and transforming human and economic relations, thus determining new social spaces of accumulation, not yet invented: that is the challenge of the cities of the year 2050 .

We must have the courage to admit that the underdevelopment in the South serves other deployment rationale of other territories; that Italy should work as a big logistic European platform in the Mediterranean Sea in order to capture and transform the effects of GDP of growth areas. And above all, we must bear in mind that the Southern question is a matter of the whole Country, therefore the 'Area of the Straits of Messina' hub is not merely a Sicilian or Calabrian issue, it is a European issue. If we do not change course and connect to the routes of future flows drawing them together, we can consider ourselves far away from growth assets. For sure, it will not be the National Operational Programme 'Smart city' or Interreg to bring into being the shocking development that we need in this part of Europe. We must trust the citizens, the young, flushing out talented people and reversing the rules of territorial planning and vision. This is a momentous turning point requiring an approach going beyond the traditional rules to sketch out new rules, the rules of territory strategic project. 


\section{References}

[1] Significantly according to art 22 of the Sicilian DDL "Metropolitan Areas, referring to art 19 of the regional decree $6^{\text {th }}$ March , $n$ 9, have specific operating methods related to the municipal functions

[2] The Sicilian reform DDL transposes the institute of the agreement already envisage by art. 117 modified by L3/2001 - art 24

[3] The National Urban Agenda has the priority task to indicate how cities will be enabled to contribute to achieving the national goals. It also indicates expected results, necessary actions and established deadlines

[4] F. Bassanini maintains that the cost of money in the Italian economic system is 2 to 4 times higher than that of competitors from Northern and Central Europe; the cost of energy is $40-60 \%$ higher; infrastructure and mobility are not competitive

[5] See: Barca's documents, Information on http://www.coesioneterritoriale.gov.it/wpcontent/; uploads/2012/12/Metodi-e-obiettivi-per-unuso-effcace-dei-fondi-comunitari-2014-20.pdf, http://www.coesioneterritoriale.gov.it/wpcontent/uploads/2012/11/Un-progetto-per-le-areeinter ne-- 15-dicembre-roma.pdf; F. Moraci: Costruire la città metropolitana di Reggio Calabria: fattori di metropolizzazione e creatività come dimensione strategica della politica urbana, in AAVV. edited by Giuseppe Tuccio, "Reggio,Città Metropolitana nell'area metropolitana dello Stretto". Iiriti ed. (2013)

[6] Urban policy is a transverse policy as it intertwines at different Government levels, State, Regions, local authorities, administrations. Furthermore, our constitutional architecture provides for a variety of institutional contexts 